\title{
The Marketing Success Factors of Thai Latex Pillow Business in China
}

\author{
Ms. Yongwen Wei, Dr. Watchara Yeesoontes \\ Graduate School of Business Administration Kasembundit University, Bangkok
}

\begin{abstract}
The primary purpose of the study was to study the influential factors of Chinese consumer purchasing Thai latex pillow behaviors. The samples were selected from 410 customers who live in China by using a check list and rating scale questionnaire as a tool. Statistical application used for data analysis percentage, mean, standard deviation, Chi-Square, and regression analysis.

On the basis of the results of this study which could be concluded that most of the respondents were females married, ages between 19-30 years old, earned lower than bachelor degree, average monthly income below 4000 CNY, most of consumers are company employees and live in the South of China.

Marketing mix which effecting customer buying behaviors of purchasing Thai latex pillow were product factors: variety brands, official seal, certified seal, and packaging trend; price factor: reasonable price, clear label, and maitain the same prices; place factor: such as convenience for transportation. Hypothesis testing revealed that factors of personal differences, such as age, marital status, income, education level and occupation effected customer purchasing behavior of Thai latex pillow business in China.

Recommendations from this study were that entrepreneurs should focus on quality of products, brands name, official seal, and certified seal, need to control the price range, comparable prices, clear prices label, and distribution channels which should be more convenient for consumers.
\end{abstract}

Keyword: marketing purpose income

\section{Introduction}

Expert studies foundthat the incidence of cervical spondylosis disease in Chinese office workers had an incidence rate of $73 \%$. Urban middle age and elderly people had an incidence rate of $82 \%$ and youth urban population the incidence rate of $36 \%$. The entire country population incidence rate of $11 \%$ as a whole. For those suffering from cervical spondylosis sleep is a very painful process where a person's life spends at least one third of the time is spent on sleep. A proper pillow can give significant help to these patients. Now in the 21st century is the digital age of technological products that are closely related to people's lives. In particular, the function of mobile phones to a large extent replaced the computer, television and movies, It is no exaggeration to say that the phone is the first thing and the last thing in a persons day. We live in such a "bow" era in this bow of the society and bow family all ages will have big problems in the body's health, especially cervical and back problems. People are constantly seeking to solve the cervical and back problems that occur from these activities.

Everyone wants and needs to have a good night's sleep. A good quality pillow is a must to have a good sleep. In recent years in the Chinese market there have been many pillows to help good sleep. The treatment with cervical pillows and pain relief pillows and one of the most popular is the memory pillow and latex pillow. With the rapid development of China's economy people's family income increase so the higher price of imported pillows are more favored by Chinese consumers. Including the Thailand latex pillow in the Chinese market which accounted for more and more of an important position. Because Thailand is close to China, Thailand is famous for tourism for many Chinese tourists who travel abroad for the first time, Thailand is the first choice for the Thai latex pillows by withstanding the site visits can be described to customers. Customers, by word of mouth, coupled with more and more stores in China's business operators carrying likable products, Thai 
suppliers will join Chinese exhibitions. The rise of WeChat direct marketing makes marketing simpler. Thailand latex pillow in China cannot be replaced in its position. Under the mission "Good Sleep, enjoy sleep, good Health",

From the introduction above, I am interested in studying the factors of the marketing success factors of Thai latex pillow business in China. For understanding the factors that influence Chinese consumers to make the decision on purchasing Thai latex pillow in China.The results from the study can be used to improve marketing strategy of Thai latex pillow business in China.

\section{The objectives of Study}

1. To study the behaviors of Chinese purchasing of the Thai latex pillow business in China.

2. To study the factors thateffect the Chinese to make the decision to purchase Thai latex pillow.

\section{Literature Review}

Research title: The marketing success factors of Thai latex pillow business in China. The student compiled concept, theory and related research are for the guidelines to set the framework, standard and using principle describe the consumers' attitude. The research is divided into: marketing mix, consumers' attitude, study documents and related research.

\section{Concept and Theory of Marketing Mix}

Philip Kotler said, 'marketing mix is the mixture of controllable marketing variable that the firm uses to pursue the sought level of sales in the target market'

\section{Research Framework}

From the study above, the study was based on the theory of the marketing, conclusion in the framework that the factors influences Chinese make decision to purchase Thai latex pillow. This study has set variables and the dependent variables.

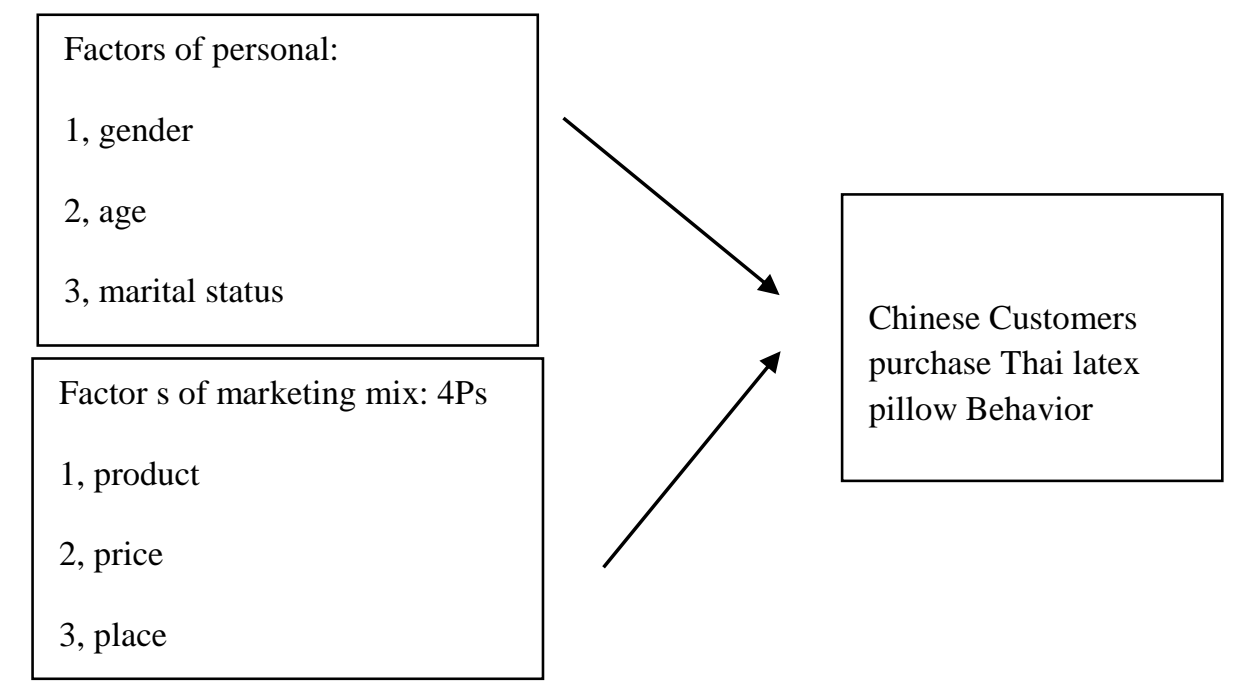

Fig. 1: Independent Variables Dependent Variables

\section{Methodology}

\subsection{Population Group Sample Source}

My study was using random sampling questionnaire survey, Chinese consumer choose buy Thai latex pillow in China. Result should keep the effective rate at $95 \%$. 


\section{Results}

The study titleThe marketing success factors of Thai latex pillow business in China. Group Examples include: Chinese consumers who buy Thai latex pillow in China. Use 410sheets questionnaires for data collection.

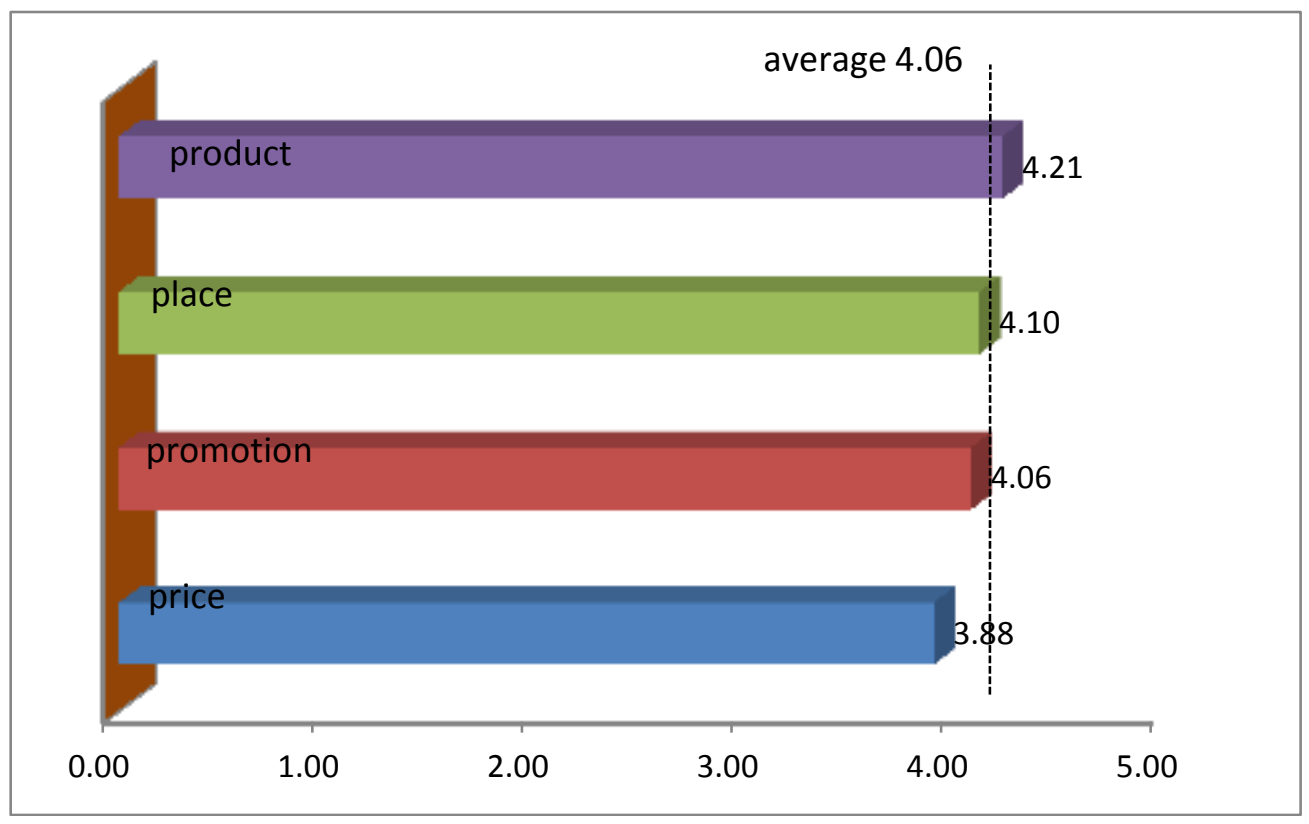

Fig. 2: Shows Information of the marketing mix factors which influence decision making to buy Thai latex pillow onthe conclusion of marketing mix.

The illustration shows the study information of the marketing mix factors which influence decision making to buy Thai latex pillow on the conclusion of marketing mix, the average value is 4.06. the product average point is 4.21 , the place average point is 4.10 , the promotion average point is 4.06 , the price average point is 3.88 .

TABLE I: Displays Important Factors That Affect The Marketing Mix For Purchasing Thai Latex Pillow By Gender.

\begin{tabular}{lrrrrr}
\hline Gender & Mean & Std. Deviation & t & df & Sig. \\
\hline Male & 356.45 & 188.70 & & & \\
\hline Female & 329.89 & 140.67 & 1.39 & 178.32 & 0.16 \\
\hline
\end{tabular}

TABLE II: Displays Important Factors That Affect The Marketing Mix For Purchasing Thai Latex Pillow By Age.

\begin{tabular}{llllll}
\hline $\begin{array}{l}\text { Important factor } \\
\text { for marketing mix }\end{array}$ & SS & df & MS & F & Sig. \\
\hline Between Groups & 393336.13 & 3.00 & 131112.04 & 5.52 & 0.00 \\
\hline Within Groups & 9638640.82 & 406.00 & 23740.49 & & \\
\hline Total & 10031976.95 & 409.00 & & & \\
\hline
\end{tabular}

TABLE III: Displays Important Factors That Affect The Marketing Mix For Purchasing Thai Latex Pillow By Marital Status.

\begin{tabular}{lrrrrr}
\hline $\begin{array}{l}\text { Important factor } \\
\text { for marketing mix }\end{array}$ & \multicolumn{1}{l}{ Sum of Squares } & \multicolumn{1}{l}{ df } & Mean Square & \multicolumn{1}{l}{ F } & \multicolumn{1}{l}{ Sig. } \\
\hline Between Groups & 883953.78 & 3.00 & 294651.26 & 13.08 & 0.00 \\
\hline Within Groups & 9148023.17 & 406.00 & 22532.08 & & \\
\hline Total & 10031976.95 & 409.00 & & & \\
\hline
\end{tabular}


TABLE IV: Displays Important Factors That Affect The Marketing Mix For Purchasing Thai Latex Pillow By Zone.

\begin{tabular}{lccccc}
\hline $\begin{array}{l}\text { Important factor } \\
\text { for marketing mix }\end{array}$ & Sum of Squares & df & Mean Square & F & \multicolumn{2}{l}{ Sig. } \\
\hline Between Groups & 8621.80 & 4.00 & 2155.45 & 0.09 & 0.99 \\
\hline Within Groups & 10023355.15 & 405.00 & 24749.03 & & \\
\hline Total & 10031976.95 & 409.00 & & & \\
\hline
\end{tabular}

TABLE V: Displays Important Factors That Affect The Marketing Mix For Purchasing Thai Latex Pillow By Income.

\begin{tabular}{lrrrrc}
\hline $\begin{array}{l}\text { Important factor } \\
\text { for marketing mix }\end{array}$ & Sum of Squares & \multicolumn{1}{c}{ df } & Mean Square & F & \multicolumn{1}{l}{ Sig. } \\
\hline Between Groups & 360152.51 & 3.00 & 120050.84 & 5.04 & 0.00 \\
\hline Within Groups & 9671824.44 & 406.00 & 23822.23 & & \\
\hline Total & 10031976.95 & 409.00 & & & \\
\hline
\end{tabular}

TABLE VI: displays important factors that affect the marketing mix for purchasing Thai latex pillow by education level.

\begin{tabular}{lccccc}
\hline $\begin{array}{l}\text { Important factor } \\
\text { for marketing mix }\end{array}$ & Sum of Squares & \multicolumn{1}{l}{ df } & Mean Square & F & \multicolumn{1}{l}{ Sig. } \\
\hline Between Groups & 518762.40 & 2.00 & 259381.20 & 11.10 & 0.00 \\
\hline Within Groups & 9513214.55 & 407.00 & 23373.99 & & \\
\hline Total & 10031976.95 & 409.00 & & & \\
\hline
\end{tabular}

TABLE VII: Displays Important Factors That Affect The Marketing Mix For Purchasing Thai Latex Pillow By Occupation.

\begin{tabular}{cccccc}
\hline $\begin{array}{c}\text { Important factor } \\
\text { for marketing mix }\end{array}$ & Sum of Squares & df & Mean Square & F & Sig. \\
\hline Between Groups & 1206800.53 & 5.00 & 241360.11 & 11.05 & 0.00 \\
\hline Within Groups & 8825176.41 & 404.00 & 21844.50 & & \\
\hline Total & 10031976.95 & 409.00 & & & \\
\hline
\end{tabular}

TABLE VIII: The Relationship Between Marketing Mix With Chinese Consumers' Behavior $\quad$ For Purchasing Of Thai Latex Pillow.

\begin{tabular}{|c|c|c|c|c|c|c|}
\hline \multirow[t]{2}{*}{ Model } & \multicolumn{2}{|c|}{$\begin{array}{l}\text { Unstandardized } \\
\text { Coefficients }\end{array}$} & \multirow{2}{*}{$\begin{array}{l}\text { Standardized } \\
\text { Coefficients } \\
\text { Beta }\end{array}$} & \multirow[b]{2}{*}{ B } & \multirow{2}{*}{$\begin{array}{l}\text { Sig. } \\
\text { Std. } \\
\text { Error }\end{array}$} & \multirow[b]{2}{*}{ relationship } \\
\hline & $\mathrm{B}$ & $\begin{array}{l}\text { Std. } \\
\text { Error }\end{array}$ & & & & \\
\hline (Constant) & 125.57 & 49.15 & & 2.55 & 0.01 & \\
\hline Variety brands & 33.59 & 11.68 & 0.17 & 2.88 & 0.00 & Yes \\
\hline Standard quality & -39.50 & 21.56 & -0.18 & -1.83 & 0.07 & No \\
\hline $\begin{array}{l}\text { Same quality } \\
\text { standard }\end{array}$ & -8.87 & 18.00 & -0.05 & -0.49 & 0.62 & No \\
\hline Quality assurance & 14.85 & 24.19 & 0.07 & 0.61 & 0.54 & No \\
\hline $\begin{array}{l}\text { Impact people's } \\
\text { health }\end{array}$ & 12.12 & 17.60 & 0.06 & 0.69 & 0.49 & No \\
\hline Official seal & 77.66 & 23.68 & 0.40 & 3.28 & 0.00 & Yes \\
\hline Certified seal & 67.33 & 28.46 & 0.34 & 2.37 & 0.02 & Yes \\
\hline Good for health & 24.70 & 22.17 & 0.12 & 1.11 & 0.27 & No \\
\hline packaging & -3.24 & 12.73 & -0.02 & -0.25 & 0.80 & No \\
\hline $\begin{array}{l}\text { Details and } \\
\text { approval }\end{array}$ & -4.22 & 22.04 & -0.02 & -0.19 & 0.85 & No \\
\hline Packaging trend & 43.85 & 16.60 & 0.26 & 2.64 & 0.01 & Yes \\
\hline More expensive & 9.15 & 11.37 & 0.06 & 0.80 & 0.42 & No \\
\hline
\end{tabular}




\begin{tabular}{|l|c|c|c|c|c|c|}
\hline Reasonable price & -39.32 & 16.19 & -0.23 & -2.43 & 0.02 & Yes \\
\hline Clear signage & -35.36 & 14.21 & -0.23 & -2.49 & 0.01 & Yes \\
\hline Price not change & 25.13 & 9.79 & 0.19 & 2.57 & 0.01 & Yes \\
\hline Places for sell & -20.37 & 8.50 & -0.16 & -2.40 & 0.02 & Yes \\
\hline Right category & -29.88 & 19.12 & -0.17 & -1.56 & 0.12 & No \\
\hline Model & $\begin{array}{c}\text { Unstandardized } \\
\text { Coefficients }\end{array}$ & $\begin{array}{c}\text { Standardized } \\
\text { Coefficients }\end{array}$ & $\mathrm{t}$ & Sig. & \\
\hline Brand display show & 10.42 & 20.91 & 0.06 & 0.50 & 0.62 & No \\
\hline $\begin{array}{l}\text { Real experience of } \\
\text { space }\end{array}$ & 10.49 & 26.18 & 0.05 & 0.40 & 0.69 & No \\
\hline Reliable and trusted & -39.66 & 23.70 & -0.21 & -1.67 & 0.10 & No \\
\hline Distance & -6.41 & 9.33 & -0.05 & -0.69 & 0.49 & No \\
\hline $\begin{array}{l}\text { Convenience } \\
\text { transportation }\end{array}$ & -108.59 & 16.58 & -0.70 & -6.55 & 0.00 & Yes \\
\hline Advertising & 9.25 & 16.11 & 0.06 & 0.57 & 0.57 & No \\
\hline Discount price & 11.93 & 15.16 & 0.07 & 0.79 & 0.43 & No \\
\hline Personal selling & 9.72 & 16.13 & 0.06 & 0.60 & 0.55 & No \\
\hline Public relations & 16.66 & 16.11 & 0.10 & 1.03 & 0.30 & No \\
\hline
\end{tabular}

\section{Conclusion}

This chapter reviews the purposes and gives a summary of the research. In addition, we also discuss the limitation of this research and provide suggestions for further study.

\subsection{Summary of Marketing Mix.}

Product factor: According to the respondents, the most respondents think the Thai latex pillow that Certified Seal to increase the credibility of pillow safety $=4.39$ points. And the average value $=4.21$ points.

Price factor: According to the respondents, the most respondents think the Thai latex pillow that Thai latex pillow expensive than ordinary pillows $=4.02$ points. And the average value $=3.88$ points .

Place factor: According to the respondents, the most respondents think the Thai latex pillow that the place to sell Thai latex pillows where is convenient and reliable can be trusted to attract customers to buy $=4.38$ points. And the average value $=4.10$ points.

Promotion factor: According to the respondents, the most respondents think the Thai latex pillow that personal selling $=4.17$ points. And the average value $=4.06$ points.

\subsection{Summary of hypothesis test}

From the analysis of data received from the questionnaires filled by consumers in China, we proved that:

Hypothesis 1: Personal different, such as gender, age, marital status, level of education, and income are affecting the behavior of purchasing Thai latex pillow..In our test, the factors of demographic have influenced customer behavior. The age factor also related with consumption frequency because the Sig. value of .000 which is lower than 0.005, and the maritalstatus factor also related with consumption frequency with Sig. value of .000. And the income factor also related with consumption frequency with Sig. value of .000 . And the education level factor also related with consumption frequency with Sig. value of .000 . And the occupation factor also related with consumption frequency with Sig. value of .000.

Hypothesis 2; Marketing mix, such as product quality, price, and warrantee are affecting the behavior of Chinese purchasing Thai latex pillow.variety brands,official seal,certified seal, packaging trend,reasonable price,clear signage,price not change, places for sell and convenience transportation have Sig. value less than 0.05, therefore it proved that marketing mix is related to Chinese consumers' behavior for purchasing of Thai latex pillow. 


\section{Future study}

This research discusses the marketing success factors of Thai latex pillow business in China which influence Chinese consumers purchasing behavior by using questionnaire and SPSS statistic program to analyze the data.

We pay more attention on marketing mix, consumer behaviors and demographic factors. For instance, when consumer purchases Thai latex pillow, they may be influenced by marketing mix, such as product, price, place, and promotion. However, the reasons that they want to buy Thai latex pillow are not discussed here and therefore should be studied further.

\section{References}

[1] Elizabeth A. Minton, Lynn R. Khale.(2014). Religion and motives for sustainablebehaviors: A cross-cultural comparison and contrast. Journal of business research.

[2] Dowhan, David.(June 1, 2013). "Hitting Your Target" . Marketing Insights. Retrieved 2016-03-30.

[3] Szwacka-Mokrzycka, Joanna.(2015). "TRENDS IN CONSUMER BEHAVIOUR CHANGES. OVERVIEW OF CONCEPTS." Acta Scientiarum Polonorum. Oeconomia. Retrieved2016-03-30.

[4] Blackwell, R. D.,Miniard, P. W., \& Engel, J. F.(2001). Consumer Behavior (9 ed.): Harcourt College Publishers Schiffman and Kanuk.(2007). Consumer Behavior, 9th Edition Kuester, Sabine (2012): MKT 301: Strategic Marketing \& Marketing in Specific Industry Contexts, University of Mannheim, p. 110.

[5] Armstrong, J Scott.1991. " Prediction of Consumer Behavior by Experts and Novices," Journal of Consumer Research, Oxford University Press, vol. 18(2), pages 251-56, September.

https://doi.org/10.1086/209257

[6] Philiop Kotler and Kevin Lane Keller.2012. Marketing Management, $14^{\text {th }}$ Edition For some classic perspectives, see Richard P.Coleman, "The Continuing Significance of Cocial Class to Marketing," Journal of Consumer Research 10 (December 1983), pp.265-80; Richard P.Coleman and see P.Rainwater, Social Standing in America: New Dimension of Class (New York: Basic Books, 1978).

[7] Abraham Maslow, Motivation and Personality (New York: Harper \& Row, 1954), pp.80-106. For an interesting business application, see Chip Conley, Peak: How Great Companies Get Their Mojo from Maslow (San Francisco: Jossey Bass2007 Per R.Dickson and Alan G.Sawyer, "The Price Knowledge: A Meta-Analysis of four decades of research." International journal of research in marketing 18 (December 2001), pp.341-55. 